Dorota Moroń

Uniwersytet Wrocławski

\title{
Polityka wobec finansowania edukacji wyższej w Polsce
}

DOI: $10.19195 / 1643-0328.20 .3$

Słowa kluczowe: szkolnictwo wyższe, finansowanie edukacji, studia odpłatne, studia nieodpłatne

\section{Wprowadzenie}

Usługi z zakresu edukacji zajmują ważne miejsce wśród usług społecznych. Należy podkreślić, że przyczyniają się one do budowy kapitału ludzkiego i społecznego, dlatego stanowią funkcjonalny element zarówno z perspektywy społecznej, jak i gospodarczej. O ile zaangażowanie państwa w organizowanie systemu oświaty i jego finansowanie nie budzi kontrowersji, o tyle w odniesieniu do edukacji wyższej, po latach akceptacji wiodącej roli państwa, coraz częściej pojawia się pytanie o obowiązek prywatnego zaangażowania osób korzystających z usług edukacyjnych. Pojawia się tu wiele uzasadnień, a koncentrują się głównie na wskazaniu jednostkowych, a nie publicznych korzyści z edukacji.

Celem badawczym jest analiza problemów dotyczących publicznego i prywatnego finansowania usług z zakresu edukacji wyższej w Polsce. Wymaga to dookreślenia samego statusu edukacji wyższej jako usługi publicznej oraz przedstawienia europejskich rozwiązań i trendów w odniesieniu do finansowania studiów wyższych. Na tym tle zostanie przeanalizowany polski system, który - w odniesieniu do aspektu finansowego - określić można mianem dualnego. Wskazanie, że prawie połowa studiujących płaci za kształcenie, skłania do postawienia pytania o faktyczną realizację zasad bezpłatności i równości dostępu do edukacji. Analiza kosztów ponoszonych przez studentów oraz możliwości wsparcia finansowego wskazują bowiem na znaczący udział prywatnych nakładów w finansowaniu edukacji wyższej.

Empiryczną podstawę analiz stanowią dane Organizacji Współpracy Gospodarczej i Rozwoju (OECD), Eurostatu oraz Głównego Urzędu Statystycznego. W artykule wykorzystane zostały przede wszystkim metoda statystyczna oraz analiza instytucjonalno-prawna. 
O ważności podjętej problematyki świadczą stale ponawiane dyskusje, dotyczące problemów finansowania studiów wyższych, publicznych oraz prywatnych nakładów na edukację.

\section{Edukacja wyższa jako usługa publiczna}

Traktowanie edukacji jako usługi publicznej, a co za tym idzie zaangażowanie państwa w dostarczanie usług edukacyjnych, sięga XVIII-XIX wieku. Jest to okres wykształcenia się narodowych systemów edukacyjnych, dla których podstawę stanowiła myśl oświeceniowa, wyrażająca się w przekonaniu, że państwo powinno przejąć obowiązek kształcenia obywateli, uzasadniając taką aktywność korzyściami społecznymi z edukacji ${ }^{1}$. Tworzone systemy edukacyjne najczęściej finansowano ze środków publicznych. Były one obowiązkowe - początkowo na poziomie podstawowym - następnie również średnim. Wyższe uczelnie, przekształcające się w nowożytne uniwersytety, dołączyły do systemów edukacyjnych przede wszystkim dzięki przejęciu przez państwo odpowiedzialności za studia wyższe i umasowieniu kształcenia wyższego.

Powstanie w Europie, po II wojnie światowej, welfare state, a więc państw realizujących funkcję opiekuńczo-socjalną, oznaczało przejęcie przez władze publiczne odpowiedzialności za prowadzenie polityki społecznej. Wiązało się to ze zwiększeniem aktywności w sferze edukacji, w tym szkolnictwa wyższego. W wielu krajach władze podjęły się prowadzenia i finansowania edukacji na poziomie wyższym, a studia stały się bezpłatne ${ }^{2}$. Podobna sytuacja miała miejsce w państwach tak zwanej demokracji ludowej.

Edukacja wyższa dołączyła więc do grona usług publicznych, które współczesne państwo świadczy na rzecz swoich obywateli. Usługi publiczne, ujmując rzecz ogólnie, to takie, które służą interesowi publicznemu, „dobra publiczne, w stosunku do których niemożliwe jest wykluczenie kogokolwiek z korzystania z nich”, „usługi świadczone przez administrację publiczną bezpośrednio ludności w ramach sektora publicznego lub podmioty prywatne zapewniające daną usługę"3. Można mówić o funkcjonowaniu klasycznych usług publicznych, wyodrębnianych na podstawie kryteriów naturalnych oraz usług mieszanych, określanych na podstawie kryteriów społecznych, stąd nazywanych często usługami społecznymi ${ }^{4}$. „Usługi mieszane są określane przez podstawowe potrzeby ludzkie i - na skutek doktryny społecznej oraz prowadzonej przez władze publiczne polityki państwa - służą całemu społeczeństwu lub zbiorowości lokalnej" 5 . Usługi publiczne cechuje zgoda społeczna, co do świadczenia ich przez sektor publiczny,

1 Zob. K. Zamorska, Prawa społeczne jako program przebudowy polityki społecznej, Wrocław 2010, s. $178-181$.

2 Bezpłatność oznacza brak konieczności uiszczania czesnego, co nie świadczy o braku obowiązku ponoszenia wybranych opłat o charakterze administracyjnym (np. opłata rejestracyjna, za wpis na semestr) czy składek na organizacje studenckie.

3 Ustugi publiczne. Organizacja i zarządzanie, red. B. Kożuch, A. Kożuch, Kraków 2011, s. 34.

${ }^{4}$ Ibidem.

5 Ibidem, s. 35. 
niezależnie od dochodu obywateli, ich podstawą są bowiem prawa człowieka ${ }^{6}$. Należy do nich edukacja, ale także między innymi usługi zdrowotne, pomoc społeczna, mieszkalnictwo czy kultura. Należy podkreślić, że w odniesieniu do tych usług nie zawsze musimy mieć do czynienia $\mathrm{z}$ ich pełną bezpłatnością oraz całkowitą dostępnością dla wszystkich zainteresowanych. Szczególnie istotne jest więc w tym zakresie zapewnienie równości dostępu do usług społecznych finansowanych ze środków publicznych.

\section{Kto powinien płacić za studia wyższe?}

Państwa dobrobytu, przejmując odpowiedzialność za politykę społeczną, w tym politykę edukacyjną, wyznaczyły standard zaangażowania publicznego w szkolnictwo wyższe, przejawiający się między innymi w prowadzeniu szkół wyższych, finansowaniu studiów i tworzeniu oraz kontroli standardów edukacyjnych. Współcześnie coraz częściej pojawiają się jednak opinie, że państwo nie powinno (nie ma środków) całkowicie finansować edukacji wyższej. Pojawia się tu wiele uzasadnień skoncentrowanych głównie na wskazaniu jednostkowych, a nie publicznych korzyści z edukacji.

Zaangażowanie państwa $\mathrm{w}$ edukację można uzasadniać zarówno argumentami o charakterze ekonomicznym, jak i społecznym oraz politycznym, przy czym współcześnie kwestie finansowe wydają się odgrywać istotną rolę. Oprócz argumentów ekonomicznych, cała dyskusja ma jednak głębsze podłoże i została ukształtowana w ramach różnych podejść teoretycznych, które koncentrując się na tych samych wartościach (równość, wolność, sprawiedliwość), różnie je interpretują.

Nicholas Barr wskazuje wprawdzie, że zyski edukacyjne bardzo trudno zmierzyć czy obliczyć, ze względu na ich różnorodność i wielowymiarowość ${ }^{7}$, podkreśla przy tym istnienie korzyści zarówno wewnętrznych (jednostkowych), jak i zewnętrznych, ogólnospołecznych, jakie niesie ze sobą wyższe wykształcenie. Z perspektywy ekonomicznej należy mówić przede wszystkim o wpływie na wysokość przyszłych podatków, związanych $\mathrm{z}$ wyższym wynagrodzeniem osób $\mathrm{z}$ dyplomem wyższej uczelni. Ponadto można wskazać na profity związane z produkcją. Osoby z wyższym wykształceniem są bardziej wydajne, łatwiej się adaptują do zmian. Nicholas Barr podkreśla, że obecnie „zaawansowane technologie plus międzynarodowa konkurencja sprawiają, że edukacja staje się ważniejszym źródłem dobrych wyników gospodarczych niż kiedykolwiek wcześniej"». Pojawiają się dziś obawy, że wykształcenie, przede wszystkim w związku z jego umasowieniem, nie stanowi gwarancji satysfakcjonującej i dobrze płatnej pracy, a czasami nawet pracy w ogóle. Ciągle jeszcze aktualna jest jednak zależność, że im wyższe wykształcenie tym niższe bezrobocie i wyższe zarobki, choć faktycznie nawet osoby wykształcone mają dziś problemy ze znalezieniem zatrudnienia.

${ }^{6}$ Ibidem, s. 34.

7 N. Barr, Państwo dobrobytu jako skarbonka. Informacja, ryzyko, niepewność a rola państwa, Warszawa 2010, s. 223.

8 Ibidem, s. 229. 
Korzyści ekonomiczne z wykształcenia można zmierzyć za pomocą wskaźnika, którym jest stopa zwrotu $\mathrm{z}$ inwestycji edukacyjnych. W Polsce, zgodnie $\mathrm{z}$ analizami przeprowadzonymi w ramach badania „Diagnoza społeczna”, licencjat zwiększa stopę zwrotu z edukacji o 5,5\%, zaś magisterium o 35,5\% w porównaniu z ukończeniem szkoły średniej, co wskazuje, że ukończenie wyższych studiów magisterskich jest dobrą inwestycją (licencjat zaś jawi się jako mało opłacalny). Doktorat zwiększa stopę zwrotu w stosunku do magistra o dalsze 36,7\%. Kobiety zyskują dużo więcej niż mężczyźni na magisterium (stopa zwrotu 43,2\%, gdy dla mężczyzn $29,9 \%$ ) i licencjacie (10,1\% do 2,4\%), ale mniej na doktoracie (tylko $29,0 \%$, podczas gdy mężczyźni $41,5 \%)^{9}$.

W ramach badań prowadzonych przez OECD analizowane są prywatne oraz publiczne koszty i korzyści edukacji wyższej. Wyniki wskazują, że prywatne korzyści z edukacji przeważają nad publicznymi (takimi jak: wpływy z podatków, składki, transfery społeczne), co może być argumentem na rzecz zwiększania prywatnych nakładów na edukację wyższą $^{10}$.

Tabela 1. Prywatne i publiczne korzyści z edukacji wyższej (dane z 2011 roku)

\begin{tabular}{l|l|c}
\hline \multicolumn{1}{c|}{ Wyszczególnienie } & Polska & Średnia dla krajów OECD \\
\hline Prywatne koszty i korzyści (mężczyźni) & $29,2 \%$ & $14,0 \%$ \\
\hline Prywatne koszty i korzyści (kobiety) & $24,0 \%$ & $11,5 \%$ \\
\hline Publiczne koszty i korzyści (mężczyźni) & $15,1 \%$ & $10,6 \%$ \\
\hline Publiczne koszty i korzyści (kobiety) & $12,6 \%$ & $8,6 \%$ \\
\hline
\end{tabular}

Źródło: Education at a Glance 2015: OECD indicators, 2015, s. 147-150.

Korzyści o charakterze społecznym i politycznym to przede wszystkim wpływ na spójność społeczną, aktywność społeczną, udział w lokalnych przedsięwzięciach i działaniach prowspólnotowych. Ma to swoją podstawę w socjalizacyjnym wymiarze edukacji - kształtuje ona postawy i przekazuje preferowane przez państwo wartości. Można również stwierdzić wpływ wykształcenia na działalność polityczną i świadomość polityczną elektoratu ${ }^{11}$.

W ostatnich latach podważony został status uniwersytetu jako instytucji dobra publicznego. Wiązało się to przede wszystkim z faktem, że zapewnienie tego typu dobra przez państwo jako dostępnego dla wszystkich zainteresowanych na równych prawach wydaje się niemożliwe, ze względu na pogłębiającą się niewydolność państwa, zarówno ekonomiczną, jak i społeczną (niezdolność poradzenia sobie z problemami społeczny-

9 J. Czapiński, Indywidualna jakość i styl życia. Diagnoza Społeczna 2015, Warunki i Jakość Życia Polaków - Raport, „Contemporary Economics” 9, 2015, nr 4, s. 238-240. W opracowaniu przedstawiono metodologię pomiaru stopy zwrotu z inwestycji edukacyjnych oraz wyniki analiz.

10 Tendencja ta nie dotyczy wszystkich państw, należy jednak pamiętać, że prywatne i publiczne korzyści w pewnym zakresie łączą się (np. wyższe zarobki wiążą się najczęściej z płaceniem wyższych podatków) i nie sposób ich rozdzielić. Wyniki analiz i metodologię przedstawiono w opracowaniu: Education at a Glance 2015: OECD indicators, 2015.

11 N. Barr, op. cit., s. 224; K. Zamorska, op. cit., s. 178-181. 
mi). Wzrost zainteresowania studiami wyższymi w Europie Zachodniej w latach 60. i 70. $\mathrm{XX}$ wieku został sfinansowany $\mathrm{z}$ budżetów, problemy budżetowe poskutkowały jednak ograniczeniem możliwości nakładów na szkolnictwo wyższe. Podstawą do wycofywania się państwa $\mathrm{z}$ zaangażowania $\mathrm{w}$ edukację wyższą stało się wykazanie, że wykształcenie wyższe to prywatna inwestycja, przynosząca korzyści osobie je zdobywającej ${ }^{12}$. Stąd ograniczanie roli państwa w finansowaniu i zarządzaniu systemem edukacji wyższej, na rzecz gwarantowania poprawnego funkcjonowania mechanizmów rynkowych. Współcześnie mamy do czynienia ze swoistą hybrydyzacją wizji uczelni jako instytucji dobra wspólnego z uczelnią jako dobrem rynkowym. Stąd możliwość wprowadzenia odpłatności przy współpłatności przez studentów i władze publiczne za studia wyższe.

Kryzys państwa opiekuńczego doprowadził do wzrostu popularności doktryny wielosektorowości, która wskazuje, że do dobrobytu społecznego (w tym poprzez świadczenie i finansowanie realizacji usług) przyczynia się nie tylko państwo (sektor publiczny), ale również sektor obywatelski (pozarządowy, non profit), sektor rynkowy (for profit) oraz sektor prywatny czy też nieformalny (np. rodzina, grupy sąsiedzkie, przyjacielskie) ${ }^{13}$. Usługi publiczne mogą więc być świadczone przez różnorodne podmioty, ponadto zdywersyfikowane mogą być ich źródła finansowania. Teoria wielosektorowości uzasadnia uruchamianie środków prywatnych, jeśli chodzi o edukację wyższą. Przedsiębiorcze uczelnie mogą pozyskiwać fundusze ze źródeł prywatnych, ponadto przedstawione powyżej teorie uzasadniają wprowadzanie odpłatności za studia wyższe. Rodzi to jednak wiele problemów, związanych choćby z wpływem osób finansujących uczelnie na ich funkcjonowanie, zadania, kierunki i programy kształcenia, standardy edukacyjne.

\section{Finansowanie edukacji wyższej w Europie}

Współczesne europejskie systemy edukacji wyższej są schedą polityki społecznej realizowanej przez welfare state, stąd duży udział władz publicznych w prowadzeniu wyższych uczelni, finansowaniu edukacji oraz kontroli jakości kształcenia. Jednocześnie rozwiązania te różnią się. Nie we wszystkich państwach udział władz publicznych jest tak znaczący.

Systemy edukacji wyższej można sklasyfikować na podstawie udziału w edukacji instytucji sektora publicznego oraz prywatnego. Klasyfikacje sporządzane przez Eurydice wskazują na funkcjonowanie trzech kategorii szkół wyższych: uczelni publicznych, uczelni prywatnych, finansowanych ze źródeł publicznych (udział funduszy publicznych powyżej 50\%) i niezależnych uczelni prywatnych (udział finansowania ze strony władz

12 K. Musiał, Uniwersytet na miare swego czasu. Transformacja społeczna $w$ dobie postindustrialnej a zmiany w szkolnictwie wyższym krajów nordyckich, Gdańsk 2013, s. 100-107.

13 Zob. D. Moroń, Trzeci sektor w teorii wielosektorowej polityki społecznej, „Wrocławskie Studia Politologiczne" 2013, nr 15, s. 7-17; eadem, Wielosektorowa polityka społeczna - wplyw globalizacji na rozwój welfare pluralism w polityce społecznej, [w:] Polityka społeczna i gospodarcza w warunkach globalizacji. Wybrane zagadnienia, red. A. Makarewicz-Marcinkiewicz, D. Pieńkowski, Poznań 2012, s. 57-75. 
publicznych poniżej 50\% $)^{14}$. Na podstawie tego kryterium można wyróżnić dwa modele funkcjonowania wyższych uczelni.

Pierwszy to model publicznego szkolnictwa wyższego, a więc system, w którym większość studentów kształcą uczelnie publiczne, a szkoły prywatne stanowią element uzupełniający ofertę kształcenia. Można tu wskazać na trzy różne rozwiązania:

1. Wyłączność szkolnictwa publicznego - dotyczy krajów, w których ponad 90\% studentów studiuje na uczelniach publicznych, obowiązuje między innymi w: Słowenii, Szwecji, Grecji, Irlandii, Niemczech, Danii, Czechach, na Słowacji, Litwie, Cyprze, we Włoszech.

2. Przewaga szkolnictwa publicznego uzupełniona uczelniami prywatnymi, finansowanymi ze źródeł publicznych - dotyczy państw, w których studenci uczelni publicznych stanowią 50-90\%, studentów, a na rynku silną pozycję mają uczelnie prywatne, dofinansowywane przez państwo. Taka sytuacja występuje między innymi na Węgrzech, w Austrii, Finlandii, Islandii i Norwegii.

3. Przewaga szkolnictwa publicznego z udziałem sektora prywatnego - tu również uczelnie publiczne mają przewagę, a ich ofertę uzupełniają szkoły prywatne, niezależne od państwa. Taka struktura dotyczy między innymi: Bułgarii, Hiszpanii, Francji, Polski, Portugalii i Rumunii.

Drugi model to model szkolnictwa prywatnego, finansowanego ze źródeł publicznych (ponad 50\% wpływów). Dominacja tego typu uczelni może być uzupełniona ofertą szkół publicznych (jak w Belgii) czy prywatnych (w Estonii i na Łotwie), ale mogą one też stanowić jedyny element systemu — dotyczy to Wielkiej Brytanii i Holandii. Co istotne, w Europie nie ma modelu funkcjonowania wyłącznie prywatnych, niezależnych uczelni. Wyraźnie więc widać zaangażowanie państwa w dostarczanie usług z zakresu edukacji wyższej.

Istotnym problemem jest relacja pomiędzy finansowaniem edukacji a obecnością na rynku edukacyjnym uczelni publicznych i prywatnych. Okazuje się, że w przypadku państw europejskich trudno mówić o prostej zależności. Fakt, że uczelnie są publiczne lub finansowane ze środków publicznych, nie oznacza, że studenci nie ponoszą żadnych kosztów kształcenia, podobnie jak fakt funkcjonowania uczelni prywatnych nie przesądza automatycznie o wysokich nakładach prywatnych. Trzeba bowiem odróżnić własność podmiotów od źródeł ich finansowania. Właśnie strumienie finansowania publicznego dla publicznych i prywatnych uczelni wyższych pozostają kwestią różnicującą. Studenci również na publicznych uczelniach czy w szkołach prywatnych dofinansowywanych przez państwo ponoszą koszty, do których mogą należeć: czesne, opłaty administracyjne czy opłaty na organizacje studenckie ${ }^{15}$. Najwyższe opłaty dotyczą takich krajów, jak: Holandia, Austria, Portugalia, Wielka Brytania, Belgia, Hiszpania, Francja czy Łotwa ${ }^{16}$.

\footnotetext{
${ }^{14}$ Key Data on Higher Education in Europe, Luxembourg 2007, s. 227.

15 Ibidem, s. 86.

16 Ibidem, s. 89-90.
} 
Analiza publicznych i prywatnych strumieni finansowania edukacji wyższej w Europie wskazuje na występowanie tu modelu dominacji publicznego finansowania. Wśród analizowanych przez OECD państw europejskich tylko Wielka Brytania, Portugalia i Węgry notują niższy niż 65\% udział publicznego finansowania. Wpisuje się ona w model dominacji prywatnego finansowania studiów, obecny między innymi w Stanach Zjednoczonych, Korei Południowej, Japonii czy Australii. Pozostałe państwa europejskie, reprezentujące model dominacji publicznego finansowania, można podzielić na dwie kategorie:

1. Publicznego finansowania studiów wyższych, co dotyczy państw, w których udział finansowania publicznego wynosi ponad 85\%. Należą do nich: Austria, Belgia, Finlandia, Islandia, Niemcy, Norwegia, Słowenia i Szwecja. Generalnie są to kraje, w których mamy do czynienia z wyłącznością szkolnictwa publicznego lub szkolnictwa publicznego z udziałem uczelni prywatnych, finansowanych ze środków publicznych.

2. Przewagi publicznego finansowania $z$ udziałem finansowania prywatnego, co ma miejsce w krajach, gdzie udział finansowania publicznego mieści się pomiędzy $65 \%$ a $85 \%$. Tutaj zaliczyć można: Czechy, Hiszpanię, Holandię, Estonię, Francję, Irlandię, Polskę, Słowację oraz Włochy. Państwa te reprezentują różne modele funkcjonowania wyższych uczelni, zarówno z wyłącznym szkolnictwem publicznym, jak i znaczącym udziałem prywatnych, niezależnych uczelni. Należy tu podkreślić znaczący udział gospodarstw domowych w finansowaniu edukacji, tylko w niektórych państwach (np. Czechy, Słowacja, Holandia) widoczny jest udział innych prywatnych źródeł finansowania (tab. 2).

Reasumując, należy stwierdzić, że europejski model finansowania szkolnictwa wyższego to finansowanie publiczne, uzupełniane - w mniejszym lub większym zakresie - źródłami prywatnymi. I chociaż w większości państw w ostatnich latach obserwuje się spadek udziału źródeł publicznych w finansowaniu edukacji wyższej (największy w Portugalii, na Węgrzech, na Słowacji, we Włoszech i w Wielkiej Brytanii ${ }^{17}$ ), fundusze publiczne pozostają jednak podstawą finansowania szkolnictwa wyższego.

Należy podkreślić, że polityka wobec szkolnictwa wyższego to nie tylko samo świadczenie usług edukacyjnych, ale również stwarzanie warunków równych szans dla wszystkich, którzy są zdolni i chętni do studiowania, oraz promowanie najlepszych. Chodzi tu o budowę systemu pomocy w ponoszeniu czesnego i opłat, wsparcia stypendialnego o charakterze socjalnym i naukowym, wsparcia mieszkaniowego, w zakresie wyżywienia, przejazdów czy wypożyczenia lub zakupu podręczników i książek naukowych, jak i pomoc rodzicom, którzy mają na utrzymaniu studiujące dzieci ${ }^{18}$. Ponadto, studenci korzystać mogą w wielu krajach z zaprojektowanych z myślą o nich systemach kredytowych na opłacenie czesnego oraz pokrycie kosztów utrzymania. Dzięki tym rozwiązaniom studia wyższe stały się dostępne dla coraz większej liczby osób.

17 Education at a Glance 2015: OECD indicators, 2015, s. 250; Education at a Glance 2012: OECD indicators, 2012, s. 259.

18 Szczegółowe rozwiązania przedstawiono w: Key Data on Higher..., s. 99-102. 
Tabela 2. Źródła finansowania edukacji wyższej w wybranych krajach (dane z 2012 roku)

\begin{tabular}{|c|c|c|c|}
\hline Państwo & Źródła publiczne (\%) & $\begin{array}{l}\text { Wydatki gospodarstw } \\
\text { domowych (\%) }\end{array}$ & $\begin{array}{c}\text { Inne źródła } \\
\text { prywatne (\%) }\end{array}$ \\
\hline Australia & 44,9 & 40,0 & 15,0 \\
\hline Austria & 95,3 & 1,9 & 2,8 \\
\hline Belgia & 89,9 & 4,9 & 5,2 \\
\hline Czechy & 79,3 & 8,5 & 12,3 \\
\hline Estonia & 78,2 & 15,2 & 6,6 \\
\hline Finlandia & 96,2 & \multicolumn{2}{|c|}{3,8} \\
\hline Francja & 79,8 & 10,6 & 9,6 \\
\hline Hiszpania & 73,1 & 23,0 & 4,0 \\
\hline Holandia & 70,5 & 15,6 & 13,9 \\
\hline Irlandia & 81,0 & 15,8 & 2,4 \\
\hline Islandia & 90,6 & 8,7 & 0,7 \\
\hline Japonia & 34,3 & 51,6 & 14,1 \\
\hline Korea Południowa & 29,3 & 42,1 & 28,6 \\
\hline Niemcy & 85,9 & \multicolumn{2}{|c|}{14,1} \\
\hline Norwegia & 96,1 & 3,3 & 0,6 \\
\hline Polska & 77,6 & 20,2 & 2,3 \\
\hline Portugalia & 54,3 & 35,0 & 10,8 \\
\hline Słowacja & 73,8 & 13,8 & 12,4 \\
\hline Słowenia & 86,1 & 11,4 & 2,5 \\
\hline Szwecja & 89,3 & 0,4 & 10,4 \\
\hline Węgry & 54,4 & \multicolumn{2}{|c|}{45,6} \\
\hline Wielka Brytania & 56,9 & 19,3 & 23,8 \\
\hline Włochy & 66,0 & 26,5 & 7,5 \\
\hline Stany Zjednoczone & 37,8 & $45,8 \%$ & $16,4 \%$ \\
\hline Kraje OECD & 69,7 & 21,7 & 10,0 \\
\hline
\end{tabular}

Źródło: Education at a Glance 2015: OECD indicators, 2015, s. 248.

\section{Konstytucyjne prawo do edukacji wyższej a odpłatność za studia}

Międzynarodowe i europejskie dokumenty poświęcone prawom społecznym jako jedno z kluczowych wskazują na prawo do edukacji ${ }^{19}$. Przede wszystkim pojawiają się w nich wskazania przymusowej i nieodpłatnej edukacji podstawowej, wprowadzania bezpłatnej nauki i zwiększania jej dostępności na szczeblu średnim i wyższym oraz równości

19 Por. K. Zamorska, op. cit. 
w dostępie do edukacji. Nie pojawia się w tym kontekście obowiązek wprowadzenia nieodpłatnego kształcenia wyższego.

W ustawodawstwie krajowym kwestia studiów wyższych i odpłatności za nie pojawia się w Konstytucji Rzeczypospolitej Polskiej z 1997 roku. Jest to pierwsza polska ustawa zasadnicza, która porusza problem szkolnictwa wyższego i odpłatności za studia ${ }^{20}$. Kluczowy w tym kontekście artykuł 70. ust 2. Konstytucji stanowi:

„Nauka w szkołach publicznych jest bezpłatna. Ustawa może dopuścić świadczenie niektórych usług edukacyjnych przez publiczne szkoły wyższe za odpłatnością"21.

Kolejne, istotne z punktu widzenia szkolnictwa wyższego, są ust. 4. i 5. o następującym brzmieniu:

4. Władze publiczne zapewniają obywatelom powszechny i równy dostęp do wykształcenia. W tym celu tworzą i wspierają systemy indywidualnej pomocy finansowej i organizacyjnej dla uczniów i studentów. Warunki udzielania pomocy określa ustawa. 5. Zapewnia się autonomię szkół wyższych na zasadach określonych w ustawie ${ }^{22}$.

Artykuł 70. jest niezwykle istotny dla określenia zasad funkcjonowania systemu szkolnictwa wyższego. Wskazuje on na funkcjonowanie w systemie dwóch typów szkół: publicznych oraz niepublicznych. Publiczne szkoły wyższe prowadzą swą podstawową działalność edukacyjną nieodpłatnie, opłaty mogą pobierać za dodatkowe usługi edukacyjne. Natomiast szkoły niepubliczne działają na klasycznych zasadach rynkowych, prowadzą działalność dla zysku i za kształcenie mają prawo pobierać opłaty. Bezpłatność stała się więc jednym z elementów prawa do edukacji, a nie kluczowym prawem dotyczącym edukacji ${ }^{23}$. Bowiem to dzięki odpłatności możliwe jest zapewnienie powszechności dostępu do studiów wyższych ${ }^{24}$.

Studia stacjonarne jako podstawową, nieodpłatną działalność uczelni usankcjonowała przyjęta jeszcze przed Konstytucją RP z 1997 roku ustawa o szkolnictwie wyższym z roku $1990^{25}$. Taką zasadę funkcjonowania wyższych uczelni publicznych utrzymało w mocy Prawo o szkolnictwie wyższym z 2005 roku $^{26}$. Wskazało ono, że wyższa uczelnia może pobierać opłaty za: kształcenie na studiach niestacjonarnych i niestacjonarnych studiach doktoranckich, powtarzanie zajęć na studiach stacjonarnych oraz stacjonarnych studiach

20 Poza Konstytucją z 1997 roku kwestia studiów wyższych pojawia się w Konstytucji Polskiej Rzeczypospolitej Ludowej z 1952 roku, która wskazuje, że prawo do nauki zapewnia między innymi stała rozbudowa szkolnictwa wyższego, zob. Konstytucja Polskiej Rzeczypospolitej Ludowej uchwalona przez Sejm Ustawodawczy w dniu 22 lipca 1952 r.: Dz.U. z 1952 r. Nr 33, poz. 232.

21 Konstytucja Rzeczypospolitej Polskiej z dnia 2 kwietnia 1997 r.; tekst jednolity: Dz.U. z 1997 r. Nr 78 , poz. 483 z późn. zm.

22 Ibidem.

23 Odpłatność za studia. Wyrok z 8 listopada 2000 r., SK 18/99, http://www.trybunal.gov.pl/omowienia/ documents/SK_18_99_PL.pdf (dostęp: 13.08.2013).

24 Ibidem.

25 Ustawa z dnia 12 września 1990 roku o szkolnictwie wyższym: Dz.U. z 1990 r. Nr 65, poz. 385. Ustawa umożliwiała pobieranie opłat w przypadku powtarzania studiów ze względu na niezadowalające wyniki w nauce.

26 Ustawa z dnia 27 lipca 2005 r. Prawo o szkolnictwie wyższym: Dz.U. z 2005 r. Nr 164, poz. 1365. 
doktoranckich $\mathrm{z}$ powodu niezadowalających wyników $\mathrm{w}$ nauce, prowadzenie studiów w języku obcym, prowadzenie zajęć nieobjętych planem studiów, studiów podyplomowych oraz kursów dokształcających, postępowanie związane z przyjęciem na studia i za wydanie dyplomu, świadectwa oraz innego dokumentu związanego z tokiem studiów ${ }^{27}$.

Doprecyzowanie zasad pobierania opłat nastąpiło w nowelizacji Prawa o szkolnictwie wyższym z 2011 roku $^{28}$. Uczelniom publicznym przyznano wówczas prawo do pobierania opłat za kształcenie na studiach stacjonarnych w przypadku studiów na drugim lub kolejnym kierunku, kształcenie na studiach stacjonarnych ponad limit punktów ECTS. Jednocześnie nowelizacja ustawy uregulowała pobieranie opłat administracyjnych, umożliwiając uczelniom ich uzyskiwanie za postępowanie rekrutacyjne oraz wydanie dyplomu, świadectwa i innego dokumentu związanego $\mathrm{z}$ tokiem studiów, ale zabroniła pobierania opłat za: rejestrację na kolejny semestr lub rok studiów, egzaminy (w tym egzamin poprawkowy, egzamin komisyjny, egzamin dyplomowy), wydanie dziennika praktyk zawodowych, złożenie i ocenę pracy dyplomowej oraz wydanie suplementu do dyplomu ${ }^{29}$.

Kwestia odpłatności za studia na drugim kierunku i ponad limit punktów ECTS stała się przedmiotem postępowania przed Trybunałem Konstytucyjnym, który w wyroku z 5 czerwca 2014 roku uznał te przepisy za niezgodne z Konstytucją RP ${ }^{30}$.

Konstytucja wskazuje także na konieczność tworzenia i wdrażania systemów pomocy materialnej tak, aby zapewnić powszechny i równy dostęp do wykształcenia. Zasada równości w dostępie do kształcenia wymaga, żeby studenci mieli możliwość korzystania ze stypendiów i wsparcia socjalnego ${ }^{31}$. Początkowo, po 1990 roku, taka możliwość była dostępna tylko dla studentów studiujących w trybie dziennym na uczelniach publicznych. Zmiany przyniosła dopiero ustawa o zmianie ustawy o szkolnictwie wyższym, ustawy o wyższych szkołach zawodowych oraz ustawy o pożyczkach i kredytach studenckich z 2005 roku, która umożliwiła korzystanie z pomocy materialnej wszystkim studentom. Rozwiązanie takie zastosowano także w nowym Prawie o szkolnictwie wyższym, wprowadzonym w tym samym roku.

Polskie prawodawstwo kreuje więc system edukacji wyższej oparty na dwóch typach studiów. Po pierwsze, są to studia nieodpłatne, wymagające ponoszenia drobnych opłat administracyjnych (np. opłata rekrutacyjna, za wydanie dyplomu). Ten wymóg spełniają studia stacjonarne na uczelniach publicznych. Po drugie, są to studia odpłatne, wymagające ponoszenia czesnego, a często również opłat administracyjnych. Należą do nich studia niestacjonarne na uczelniach publicznych oraz studia na uczelniach niepublicznych.

27 Ibidem.

28 Na mocy Ustawy z dnia 18 marca 2011 r. o zmianie ustawy — Prawo o szkolnictwie wyższym, ustawy o stopniach naukowych i tytule naukowym oraz o stopniach i tytule w zakresie sztuki oraz o zmianie niektórych innych ustaw: Dz.U. z 2011 r. Nr 84, poz. 455.

29 Ustawa z dnia 27 lipca 2005 r. Prawo o szkolnictwie wyższym; tekst jednolity: Dz.U. z 2012 r., poz. 572 z późn. zm.

30 Odpłatność za studia w uczelniach publicznych. Wyrok z 5 czerwca 2014 r., SK 35/11, http://trybunal.gov.pl/rozprawy-i-ogloszenia-orzeczen/wyroki-i-postanowienia/art/6890-odplatnosc-za-studia-wuczelniach-publicznych/ (dostęp: 5.03.2016).

31 Odpłatność za studia. Wyrok z 8 listopada 2000 r. 


\section{System edukacji wyższej w Polsce w kontekście finansowania edukacji}

Jeśli system edukacji wyższej zakłada współwystępowanie studiów płatnych i nieodpłatnych to podstawowe wydaje się pytanie o publiczne i prywatne strumienie finansowania studiów wyższych. Wprawdzie modelowo finansowanie szkolnictwa wyższego opiera się na środkach publicznych jako podstawowych, w praktyce funkcjonują jednak dwa odrębne systemy finansowania studiów wyższych:

Studia nieodpłatne - nie wymagają opłaty w postaci czesnego, chociaż w większości przypadków wiążą się z ponoszeniem opłat administracyjnych. Podstawowym rodzajem studiów są tu studia stacjonarne I, II i III stopnia oraz jednolite magisterskie na uczelniach publicznych. System ten uzupełniają inne typy studiów wyższych na uczelniach publicznych oraz studia na uczelniach niepublicznych, które są finansowane ze środków publicznych, na przykład w ramach Programu Kierunków Zamawianych realizowanego w perspektywie finansowej Unii Europejskiej na lata 2007-2013 (zastąpionego w perspektywie 2014-2020 Programem Wspierania Kompetencji) czy w ramach innych projektów finansowanych ze środków europejskich.

Studia odpłatne - wymagające opłaty w postaci czesnego, a najczęściej również opłat administracyjnych. Można wśród nich wyróżnić dwa typy studiów:

- studia odpłatne na uczelniach publicznych — przede wszystkim studia niestacjonarne, ale także studia podyplomowe czy studia prowadzone w językach obcych. Studia odpłatne stanowić powinny dodatkową aktywność uczelni, ponadto ustalając wysokość kosztów powinny one brać pod uwagę faktyczne koszty kształcenia;

- studia odpłatne na uczelniach niepublicznych - studia prowadzone na uczelniach niepublicznych, $\mathrm{w}$ trybie stacjonarnym i niestacjonarnym, oparte na mechanizmie rynkowym, ponieważ szkoły niepubliczne są podmiotami, które mogą być nastawione na zysk. Prowadzą je organizacje pozarządowe w ramach działalności statutowej, ale również podmioty rynkowe dla osiągnięcia zysku, stąd wysokość opłat uwzględnia tu opłacalność przedsięwzięcia.

Dane dotyczące studentów studiów I i II stopnia oraz studiów jednolitych pozwalają na wskazanie pewnych prawidłowości. Na uczelniach publicznych większość osób studiuje $\mathrm{w}$ trybie stacjonarnym, nieodpłatnym, a odsetek osób studiujących stacjonarnie systematycznie rośnie - w 2014 roku było to aż $77 \% 32$ (ryc. 1). Wynika to z dwóch czynników. Po pierwsze, wzrostu liczby miejsc na studiach dziennych, po drugie, z niżu demograficznego, który sprawia, że mniej osób jest zainteresowanych studiami. W związku z tym ostatnim coraz większe są szanse studiowania w trybie dziennym, stąd mniej chętnych na studia niestacjonarne.

32 Najwięcej od 1994 roku. Nie są dostępne dane z lat 1990-1993 z podziałem na typ uczelni i rodzaj studiów. 


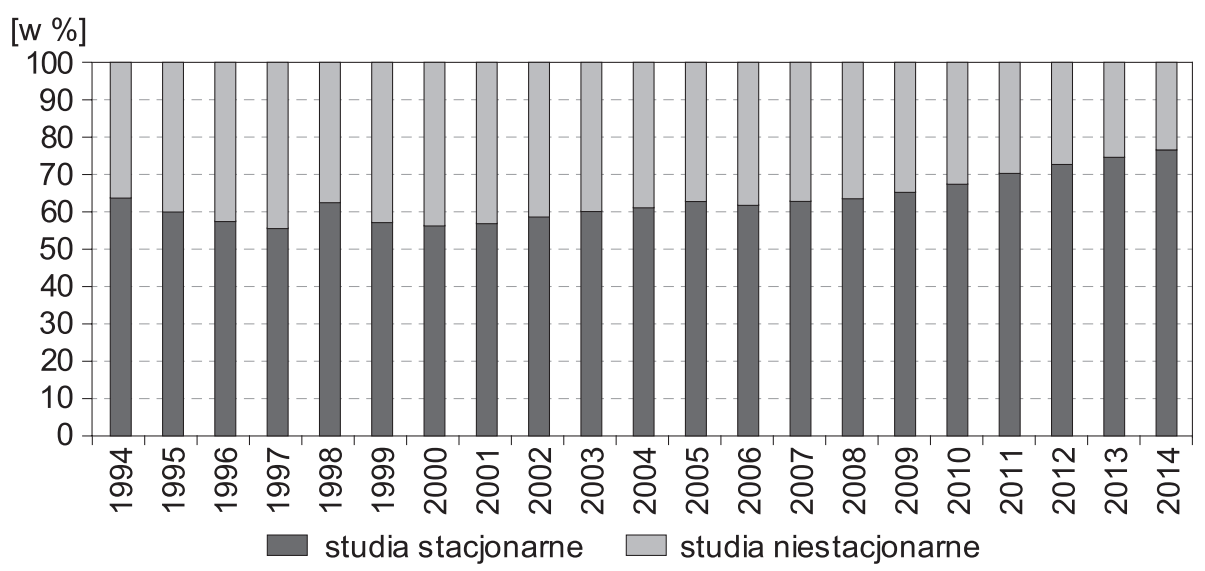

Rycina 1. Studenci studiów stacjonarnych i niestacjonarnych na uczelniach publicznych w Polsce w latach $1994^{\star}-2014$

* Nie są dostępne dane z lat 1990-1993 z podziałem na typ uczelni i rodzaj studiów.

Źródło: Rocznik statystyczny 1991, Warszawa 1991, s. 439-440; Rocznik statystyczny 1992, Warszawa 1992, s. 411, 422; Rocznik statystyczny 1993, Warszawa 1993, s. 428, 440; Rocznik statystyczny 1994, Warszawa 1994, s. 475, 487; Szkoty wyższe w roku szkolnym 1994/95, Warszawa 1995, s. 2; Szkoły wyższe w roku szkolnym 1995/96, Warszawa 1996, s. 2; Szkoły wyższe w roku szkolnym 1996/97, Warszawa 1997, s. 2; Bank Danych Lokalnych Głównego Urzędu Statystycznego, http://www.stat.gov.pl/bdl (dostęp: 5.03.2016).

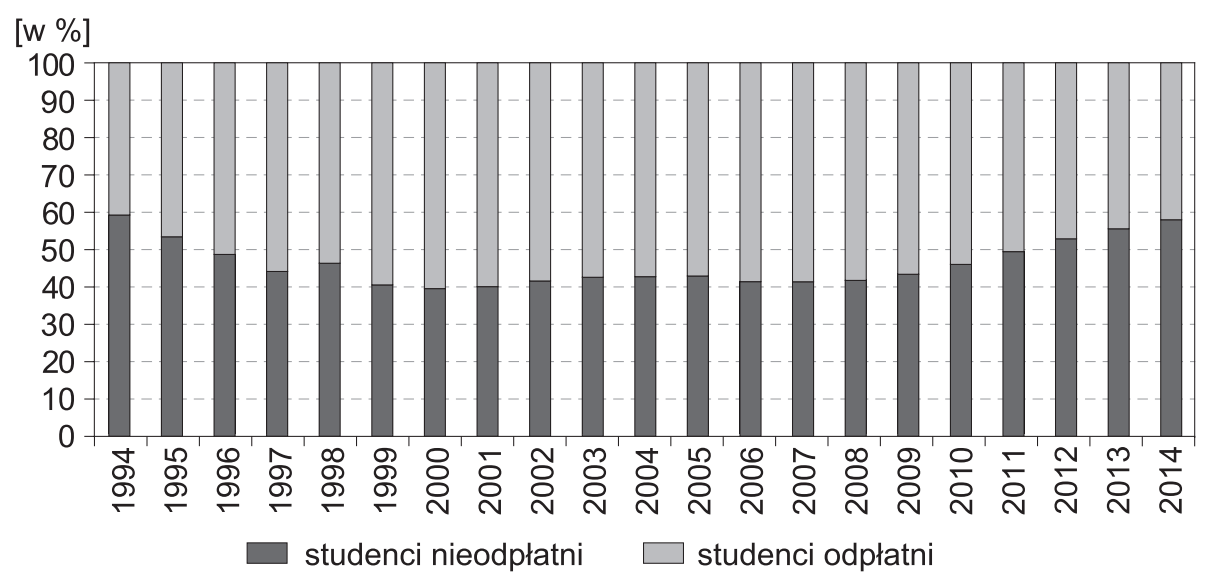

Rycina 2. Studenci studiujący na studiach odpłatnych i nieodpłatnych w Polsce w latach $1994^{\star}-2014$

* Nie są dostępne dane z lat 1990-1993 z podziałem na typ uczelni i rodzaj studiów.

Źródło: Rocznik statystyczny 1991, Warszawa 1991, s. 439-440; Rocznik statystyczny 1992, Warszawa 1992, s. 411, 422; Rocznik statystyczny 1993, Warszawa 1993, s. 428, 440; Rocznik statystyczny 1994, Warszawa 1994, s. 475, 487; Szkoty wyższe w roku szkolnym 1994/95, Warszawa 1995, s. 2; Szkoły wyższe w roku szkolnym 1995/96, Warszawa 1996, s. 2; Szkoły wyższe w roku szkolnym 1996/97, Warszawa 1997, s. 2; Bank Danych Lokalnych Głównego Urzędu Statystycznego, http://www.stat.gov.pl/bdl (dostęp: 5.03.2016).

Gdy jednak odniesiemy udział studentów studiujących w trybie stacjonarnym na uczelniach publicznych, a więc nieodpłatnie, do studentów pozostałych, płacących za 
studia (niestacjonarne na uczelniach publicznych lub studia na uczelniach niepublicznych), okazuje się, że studenci nieodpłatni mają liczebną przewagę nad płacącymi dopiero od 2012 roku (licząc od 1996 roku; ryc. 2). W 2014 roku studenci, którzy nie płacili za edukację, stanowili 58\% ogółu studentów. Wprowadzenie odpłatności, przy niewystarczających środkach na edukację wyższą, faktycznie stanowi formę zwiększania dostępności studiów, jednakże należy się zastanowić jednak czy jest to tylko sposób na zwiększenie oferty, z której skorzystają wybrani studenci, czy tryb studiów równoważny studiom nieodpłatnym.

Należy zauważyć, że na uczelniach studiują również studenci studiów doktoranckich oraz słuchacze studiów podyplomowych. Z 43399 uczestników studiów doktoranckich bezpłatnie, a więc $\mathrm{w}$ trybie stacjonarnym na uczelniach publicznych studiowało $78 \%$, natomiast $15 \%$ studiowało niestacjonarnie na uczelniach publicznych i $7 \%$ uczyło się na uczelniach niepublicznych - czyli w trybach odpłatnych ${ }^{33}$. Wśród płacących za edukację słuchaczy studiów podyplomowych (których w 2014 roku było 149 799) 60\% uczyło się na uczelniach publicznych, a $40 \%$ na niepublicznych ${ }^{34}$.

Wielość uczelni, kierunków i trybów kształcenia daje kandydatom na studentów duży wybór. Od strony finansowej wymaga on analizy kosztów studiowania oraz potencjalnych możliwości uzyskania wsparcia finansowego ze źródeł publicznych (stypendia, miejsce w domu studenckim, obiady w stołówkach). Należy pamiętać, że samo czesne i opłaty administracyjne to tylko część kosztów, które ponosi student. W kalkulacji konieczne jest również uwzględnienie wydatków na zakup podręczników, ksero, dojazdy, zamieszkanie czy wyżywienie. Te wszystkie koszty łącznie dają obraz prywatnych wydatków ponoszonych na edukację wyższą.

Czesne, w przypadku studiów odpłatnych, jest bardzo ważną pozycją w budżecie studenta. Koszt studiów zależy przede wszystkim od kierunku studiów i konkretnej uczelni. Nie zawsze jest tak, że studia w uczelniach publicznych, nienastawionych na zysk, są tańsze. Eksperci Instytutu Sokratesa, analizując ceny studiów w roku 2010/2011, wskazali, że wahały się od nieco ponad $1000 \mathrm{zł}$ do ponad $11000 \mathrm{zł} \mathrm{za} \mathrm{semestr.} \mathrm{Do} \mathrm{najdroższych}$ należały kierunki medyczne (lekarsko-dentystyczny, lekarski, farmacja), a także kierunki artystyczne i niektóre przyrodnicze oraz techniczne, zaś do najtańszych - teologia, muzykologia, filozofia czy bibliotekoznawstwo ${ }^{35}$. Dodatkowo przeanalizowali znaczące, sięgające czasami nawet 50\%, różnice między cenami poszczególnych kierunków na uczelniach publicznych i niepublicznych. Są kierunki, które - jak podkreślają autorzy — „opłaca się” studiować na uczelniach publicznych i takie, które są tańsze na uczelniach niepublicznych ${ }^{36}$. Różnice te wynikają z wielu czynników wpływających na kalkulację opłat za konkretny kierunek, stąd nie można wskazać, że status uczelni (publiczna v. niepubliczna) determinuje wysokość opłat.

33 Szkoły wyższe i ich finanse w 2014 r., Warszawa 2015, s. 159.

34 Ibidem, s. 150.

35 D. Antonowicz, B. Gorlewski, (Bez)płatne studia 2011. Raport na temat cen studiów w Polsce w roku 2010/2011, 2011, s. 5-6, http://instytutsokratesa.pl/pliki/Instytut_Sokratesa_ceny_studiow_2011.pdf (dostęp: 1.04.2016).

36 Ibidem, s. 9-10. 
Przy założeniu finansowania edukacji, w tym edukacji wyższej ze środków publicznych, w praktyce wyraźnie wydać podział na segment edukacji nieodpłatnej oraz odpłatnej, w szkołach publicznych i niepublicznych. Studenci, którzy płacą za studia, nie stanowią marginesu, ale pokaźną grupę studiujących. Pojawia się więc w tym kontekście pytanie o rozumienie równości $\mathrm{w}$ dostępie do edukacji wyższej. Czy faktycznie studia odpłatne gwarantują dostęp do edukacji? Czy odpłatność kreuje podział na tych, którzy, spełniając dodatkowe kryteria, mogą się uczyć nieodpłatnie, i tych, którzy z różnych przyczyn za studia muszą płacić? Wydaje się, że teza o zapewnieniu dostępu do edukacji poprzez system odpłatnych studiów stanowi uzasadnienie niedostatecznego finansowania studiów wyższych z budżetu państwa.

\section{Publiczne i prywatne nakłady na edukację wyższą}

Wskazanie, że prawie połowa studentów płaci za studia wyższe, skłania do zastanowienia się nad znaczeniem publicznego i prywatnego strumienia środków finansujących edukację wyższą. Ogólnie przychody z działalności dydaktycznej są podstawowymi przychodami wyższych uczelni (77,9\% przychodów), w szkołach publicznych stanowią $77,3 \%$ przychodów, zaś w niepublicznych 82,9\%. Uczelnie niepubliczne najczęściej nastawione są głównie na dydaktykę, w przypadku szkół publicznych przychody w większym stopniu czerpane są z działalności badawczej $(14,9-4,3 \%)^{37}$.

Strumień środków budżetowych stanowi 68,8\% środków na dydaktyczną działalność uczelni ${ }^{38}$. Oczywiście, można powiedzieć, że to dużo. Przy założeniu finansowania edukacji ze środków publicznych udział ten nie wydaje się jednak wystarczający. Środki na działalność dydaktyczną pochodzą więc dodatkowo $\mathrm{z}$ opłat za zajęcia dydaktyczne $(20,6 \%)$ i innych źródeł $(10,4 \%)^{39}$. Udział środków publicznych w ostatnich latach utrzymuje się na podobnym poziomie, widać jednocześnie wzrost udziału innych źródeł finansowania i spadek udziału z opłat za zajęcia dydaktyczne $e^{40}$.

W przypadku działalności dydaktycznej głównym źródłem funduszy dla uczelni publicznych jest budżet państwa, który wnosi 76,9\% przychodów, opłaty studentów to $12,1 \%$. Odwrotna tendencja jest w uczelniach niepublicznych, które $82,4 \%$ przychodów czerpią z czesnego (ryc. 3.). Widać więc, że środki z opłat nie stanowią znaczącej pozycji w budżetach szkół publicznych, pozwalają jednak na realizację zadań statutowych uczelni i pełnią funkcję uzupełniającą przy znaczących potrzebach finansowych szkół. Należy podkreślić, że wpływy z czesnego maleją, w 2005 roku w szkołach publicznych z opłat pochodziło $20,0 \%$ przychodów, a w niepublicznych $95,1 \%{ }^{41}$. Również szkoły niepublicz-

37 Szkoly wyższe i ich finanse w 2014 r., s. 184.

38 Dodatkowo $0,1 \%$ środków to środki publiczne z budżetów gmin i innych funduszy publicznych. Ibidem, s. 188.

39 Ibidem.

40 Por. Szkoły wyższe i ich finanse w 2004 r., Warszawa 2005, s. 360; Szkoly wyższe i ich finanse w 2005 r., Warszawa 2006, s. 312; Szkoly wyższe i ich finanse w 2008 r., Warszawa 2009, s. 324.

41 Szkoly wyższe i ich finanse w 2005 r., s. 312. 
ne zaczęły czerpać fundusze budżetowe i, choć skala jest nieporównywalna z uczelniami publicznymi, wzrost z 0,2\% w 2005 roku $^{42}$ do 10,3\% w 2014 jest znaczący.

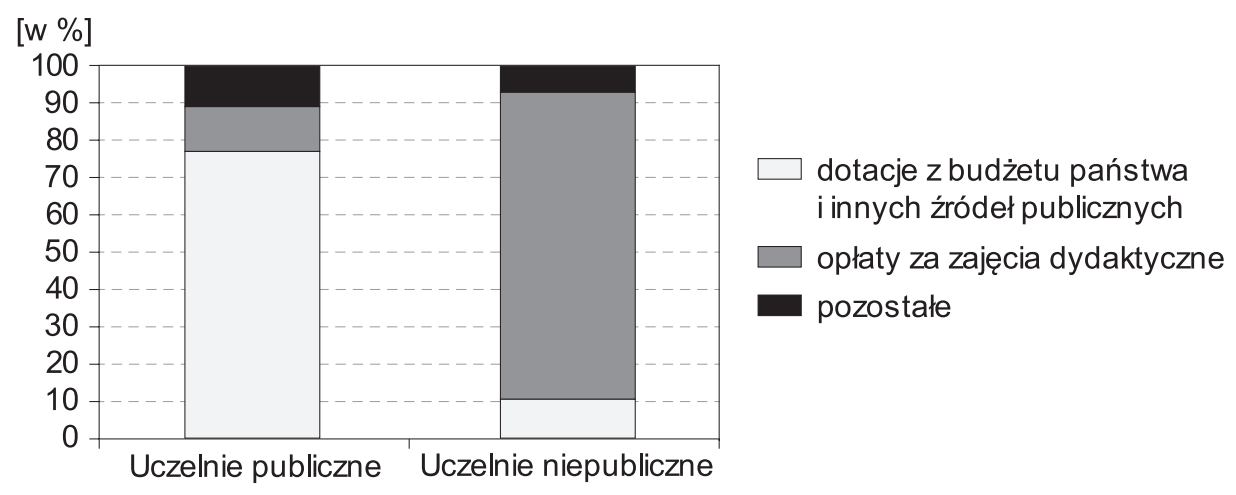

Rycina 3. Przychody z działalności dydaktycznej szkół wyższych w Polsce w 2014 roku

Źródło: Szkoły wyższe i ich finanse w 2014 r., Warszawa 2015, s. 188.

Należy podkreślić, że koszty działalności dydaktycznej szkół publicznych są znacząco wyższe niż niepublicznych. W 2014 roku koszt na studenta przeliczeniowego wyniósł 16,2 tys. zł w szkołach publicznych i 8,2 tys. w niepublicznych ${ }^{43}$. Wynika to z wielu przyczyn, a ponieważ przesądzają one o braku możliwości konkurencji pomiędzy szkołami publicznymi i niepublicznymi, warto wskazać na najważniejsze z nich. Po pierwsze, różnica ta wiąże się z bardzo wysokimi kosztami kształcenia na niektórych kierunkach studiów, najczęściej dostępnych wyłącznie na uczelniach publicznych. Koszt jednostkowy edukacji na publicznych uczelniach medycznych wyniósł 30,7 tys. zł, a na uczelniach artystycznych 38,2 tys. zł rocznie. Najtaniej kształcą wyższe szkoły ekonomiczne - to wydatek 10,9 tys. na studenta ${ }^{44}$. Po drugie, większa liczba studentów szkół publicznych kształci się w systemie stacjonarnym, korzysta więc $\mathrm{z}$ większej liczby godzin zajęć dydaktycznych, co generuje koszty. Po trzecie, szkoły publiczne utrzymują zwykle znacząco większą bazę lokalową (budynki dydaktyczne, biblioteki, obiekty sportowe) i więcej zatrudnionych na etacie wykładowców. W 2014 roku w uczelniach publicznych jeden pełnozatrudniony nauczyciel akademicki przypadał na 14 studentów przeliczeniowych, zaś w uczelniach niepublicznych na $24^{45}$. Nie zawsze musi to oznaczać większe grupy zajęciowe, chociaż szkoły niepubliczne zwykle nie prowadzą kierunków wymagających małych grup laboratoryjnych czy ćwiczeniowych. Bardzo często zatrudniają natomiast pracowników na umowy cywilnoprawne, co pozwala na obniżanie kosztów. Typowa rynkowa konkurencja między sektorem publicznym i prywatnym w szkolnictwie wyższym w takim układzie prawnym nie jest więc możliwa.

\footnotetext{
42 Ibidem.

43 Koszt obejmuje koszty własne działalności dydaktycznej, pomoc materialną dla studentów wraz z własnym funduszem stypendialnym; Szkoły wyższe i ich finanse w 2014 r., s. 208.

44 Ibidem.

45 Ibidem, s. 164, 209.
} 


\section{Podsumowanie}

Polski system finansowania wyższych uczelni modelowo należy do systemów finansowania publicznego, uzupełnianego dodatkowo źródłami prywatnymi, przede wszystkim wpływami z czesnego. W praktyce generuje jednak dwie odrębne formuły finansowania studiów wyższych - inną w przypadku studiów bezpłatnych i odpłatnych. Podstawowe finansowanie ze źródeł publicznych nie eliminuje konieczności ponoszenia kosztów czesnego przez studentów studiujących w formach odpłatnych. Bezpłatność nauczania na poziomie wyższym jest tylko jednym $z$ elementów systemu, a nie prawem każdego studiującego. I chociaż Trybunał Konstytucyjny potwierdził konstytucyjność takiego rozwiązania i zapewnianie przezeń nie tylko równości, ale również dostępności wyższego wykształcenia nie zmienia to faktu, że wielu obywateli musi ponosić większe koszty związane z edukacją, płacąc za studia wyższe.

Z perspektywy finansowej polski system promuje uczelnie publiczne, a wprowadzona już od lat 90. XX wieku wielosektorowość, a więc udział uczelni niepublicznych, prowadzonych przez sektor prywatny i pozarządowy w rynku edukacyjnym, była w zamyśle państwa zaledwie uzupełnieniem oferty publicznej, istotnym w kontekście dużego zainteresowania studiami. Chociaż polskie szkolnictwo wyższe jest oparte na uczelniach publicznych i publicznym finansowaniu, coraz większą rolę odgrywają i będą odgrywały prywatne środki wydatkowane na edukację wyższą. Początkowo główną rolę wśród nich odgrywały fundusze $\mathrm{z}$ budżetów gospodarstw domowych transferowane $\mathrm{w}$ formie czesnego, dziś coraz większy nacisk kładzie się na pozyskiwanie ich z innych źródeł, na przykład z funduszy europejskich czy na podstawie współpracy $\mathrm{z}$ podmiotami gospodarczymi.

Nacisk na pozyskiwanie przez uczelnię funduszy, w tym na działalność dydaktyczną, wiąże się z ograniczonymi środkami budżetu państwa. Wydaje się jednak, że podejmując działalność związaną z prowadzeniem wyższych uczelni, władze publiczne powinny wziąć na siebie odpowiedzialność za ich prowadzenie. Oczywiście, reformy publicznych uczelni w kierunku racjonalizacji wydatków i sprawnego zarządzania finansami są potrzebne, nie powinny one jednak oznaczać automatycznego wycofywania się państwa z przyjętych zobowiązań. Na edukację należy patrzeć perspektywicznie, efekt końcowy widać bowiem dopiero po kilku czy kilkunastu latach. Nie zawsze podmioty prywatne czy pozarządowe są zdolne do takich analiz czy inwestycji. Dlatego państwu powinna przypadać kluczowa rola w tym zakresie.

Równości dostępu do edukacji wyższej niewątpliwie sprzyja postępujący niż demograficzny na uczelniach. Coraz większe są możliwości studiów bezpłatnych, co ogranicza liczbę osób kształcących się w formach odpłatnych. Brak środków finansowych nie daje raczej szansy na wprowadzenie powszechnej bezpłatności studiów wyższych, nie należy się więc spodziewać znaczących zmian w zakresie finansowania studiów wyższych w najbliższych latach. 


\section{Bibliografia}

Barr N., Państwo dobrobytu jako skarbonka. Informacja, ryzyko, niepewność a rola państwa, WSP TWP, Warszawa 2010.

Czapiński, J., Indywidualna jakość i styl życia. Diagnoza Społeczna 2015, Warunki i Jakość Życia Polaków Raport, „Contemporary Economics” 9, 2015, nr 4.

Education at a Glance 2015: OECD indicators, 2015.

Education at a Glance 2012: OECD indicators, 2012.

Key Data on Higher Education in Europe, Luxembourg: Office for Official Publications of the European Communities, Luxembourg 2007.

Konstytucja Polskiej Rzeczypospolitej Ludowej uchwalona przez Sejm Ustawodawczy w dniu 22 lipca 1952 r.: Dz.U. z 1952 r. Nr 33, poz. 232.

Konstytucja Rzeczypospolitej Polskiej z dnia 2 kwietnia 1997 r.; tekst jednolity: Dz.U. z 1997 r. Nr 78, poz. 483 z późn. $z m$.

Moroń D., Trzeci sektor $w$ teorii wielosektorowej polityki społecznej, „Wrocławskie Studia Politologiczne” 2013, nr 15.

Moroń D., Wielosektorowa polityka społeczna - wplyw globalizacji na rozwój welfare pluralism w polityce społecznej, [w:] Polityka społeczna i gospodarcza w warunkach globalizacji. Wybrane zagadnienia, red. A. Makarewicz-Marcinkiewicz, D. Pieńkowski, Agencja Reklamowa Prodruk, Poznań 2012.

Musiał K., Uniwersytet na miare swego czasu. Transformacja społeczna $w$ dobie postindustrialnej a zmiany w szkolnictwie wyższym krajów nordyckich, Wydawnictwo Uniwersytetu Gdańskiego, Gdańsk 2013.

Szkoły wyższe i ich finanse w $2014 \mathrm{r}$., Warszawa 2015.

Szkoły wyższe i ich finanse w 2004 r., Warszawa 2005.

Szkoty wyższe i ich finanse $w 2005$ r., Warszawa 2006.

Szkoły wyższe i ich finanse w $2008 \mathrm{r}$., Warszawa 2009.

Ustugi publiczne. Organizacja i zarzadzanie, red. B. Kożuch, A. Kożuch, Instytut Spraw Publicznych Uniwersytetu Jagiellońskiego, Kraków 2011.

Ustawa z dnia 12 września 1990 r. o szkolnictwie wyższym: Dz.U. z 1990 r. Nr 65, poz. 385.

Ustawa z dnia 12 września 1990 r. o szkolnictwie wyższym; tekst jednolity: Dz.U. z 1990 r. Nr 65, poz. 385 z późn. zm.

Ustawa z dnia 27 lipca 2005 r. Prawo o szkolnictwie wyższym: Dz.U. z 2005 r. Nr 164, poz. 1365.

Ustawa z dnia 27 lipca 2005 r. Prawo o szkolnictwie wyższym; tekst jednolity: Dz.U. z 2012 r. Nr 0, poz. 572 z późn. $\mathrm{zm}$.

Ustawa z dnia 18 marca 2011 r. o zmianie ustawy — Prawo o szkolnictwie wyższym, ustawy o stopniach naukowych i tytule naukowym oraz o stopniach i tytule w zakresie sztuki oraz o zmianie niektórych innych ustaw: Dz.U. z 2011 r. Nr 84, poz. 455.

Ustawa z 7 stycznia 2005 r. o zmianie ustawy o szkolnictwie wyższym, ustawy o wyższych szkołach zawodowych oraz ustawy o pożyczkach i kredytach studenckich: Dz.U. z 2005 r. Nr 23, poz. 187.

Zamorska K., Prawa społeczne jako program przebudowy polityki społecznej, Wydawnictwo Uniwersytetu Wrocławskiego, Wrocław 2010.

\section{Źródła internetowe}

Antonowicz D., Gorlewski B., (Bez)płatne studia 2011. Raport na temat cen studiów w Polsce w roku 2010/2011, 2011; http://instytutsokratesa.pl/pliki/Instytut_Sokratesa_ceny_studiow_2011.pdf

Bank Danych Lokalnych Głównego Urzędu Statystycznego, http://www.stat.gov.pl/bdl

Odpłatność za studia. Wyrok z 8 listopada 2000 r., SK 18/99, http://www.trybunal.gov.pl/omowienia/documents/SK_18_99_PL.pdf 


\section{Policy towards the higher education financing in Poland}

Keywords: higher education, education financing, paid studies, tuition free studies

\section{Summary}

The article provides an analysis of the issue related to public and private financing of higher education in Poland. The arguments for the systems of public, private, or mixed financing of studies are compared here with the European models of financing higher education. This paper analyses the Polish system of financing education in the context of both legal bases and the reality in the operation of higher education institutions. The analysis indicates that the system of financing public higher education is in fact dual, i.e. it consists of paid studies and tuition free studies. The fact that almost half of the students pay for their education triggers a question whether education is really free and whether everyone has equal access to education. The analysis of the costs incurred by the students and the possibilities to gain financial support indicates a significant percentage of private expenditures in financing higher education.

The mixed system of financing higher education in Poland and the existence of public and non-public higher schools prove that the entities providing higher education services as well as the flows of funds for higher schools are diversified. Thus, the citizens can use public education services but often they are obliged to pay for the service. 